\title{
СОВРЕМЕННОЕ СОЦИАЛЬНО-ЭКОНОМИЧЕСКОЕ СОСТОЯНИЕ И ПЕРСПЕКТИВНЫЕ НАПРАВЛЕНИЯ РАЗВИТИЯ ЮГА РОССИИ
}

\section{THE CURRENT SOCIO-ECONOMIC STATUS AND PROMISING AREAS OF DEVELOPMENT OF THE SOUTH OF RUSSIA}

M. Ramazanova

Summary. The article analyzes the dynamics of indicators of industrial and agricultural production in the federal districts of the Russian Federation, reveals the place of the South of Russia in interregional comparisons, the factors that form the competitive advantages of the macroregion, substantiate organizational, economic and regulatory measures aimed at stimulating social and economic development. The results of the study can be used by public authorities, investors in the management of financial activities, investment planning in the medium and long term.

Keywords: region, economy, development, South of Russia, federal okrug.

\author{
Рамазанова Марина Юсуфовна \\ К.э.н., дочент, ГАОУ ВО «Дагестанский \\ государственный университет народного хозяйства», \\ 2. Махачкала \\ Eminowa.marina@yandex.ru
}

Аннотация. В статье анализируется динамика показатели промышленного и сельскохозяйственного производства в федеральных округах Российской Федерации, выявляется место Юга России в межрегиональных сопоставления, факторы, формирующие конкурентные преимущества макрорегиона, обосновываются организационно-экономические и нормативно-правовые мероприятия, направленные на стимулирование социально экономического развития. Результаты исследования могут использоваться органами государственной власти, инвесторами при управлении финансовой деятельностью, планировании капиталовложений в средне- и долгосрочной перспективе.

Ключевые слова: регион, экономика, развитие, Юг России, федеральный округ.

валового регионального продукта на душу населения (таблицы 1, 2, 3).

Согласно научной точке зрения автора, такие административно-территориальные единицы Российской Федерации, как Южный и Северо-Кавказский федеральный округа, при разработке направлений государственной социально-экономической политики целесообразно рассматривать как Южно-Российский макрорегион (Юг России). Обозначенный тезис подтверждается следующими основными аргументами: 1. Тесная хозяйственная взаимосвязь субъектов РФ, входящих в состав указанных федеральных округов, 2. Географическое пространственное единство территории, ограниченной с востока - Каспийским морем, с запада - государственной границей РФ, с юга - Кавказским горным массивом и бассейнами Чёрного и Азовского морей, с северо-запада и северо-востока - административными границами Центрального и Приволжского федеральных округов соответственно.

Анализ информации, представленной в таблицах 1, 2 позволяет отметить место Юга России общероссийских сопоставлениях. Доля Юга России в производстве сельскохозяйственной продукции снижается с 26,0\% в 2016 г. до 25,5\% в 2018 г. При этом, отмечаются разнонаправленные тенденции: производство сельхозпродукции в Северо-Кавказском федеральном округе (СКФО) возрастает 
Таблица 1. Производство сельскохозяйственной продукции в РФ за период 2014-2018 гг.

\begin{tabular}{|c|c|c|c|c|c|c|c|c|}
\hline \multirow{3}{*}{ Наименование } & \multicolumn{6}{|l|}{ Годы } & \multirow{2}{*}{\multicolumn{2}{|c|}{ Динамика }} \\
\hline & \multicolumn{2}{|l|}{2016} & \multicolumn{2}{|l|}{2017} & \multicolumn{2}{|l|}{2018} & & \\
\hline & млн. руб. & $\%$ & млн. руб. & $\%$ & млн. руб. & $\%$ & млн. руб. & $\%$ \\
\hline $\begin{array}{l}\text { Дальневосточный } \\
\text { федеральный округ }\end{array}$ & 188 & 3,7 & 200 & 3,9 & 199 & 3,7 & 11 & 0,0 \\
\hline $\begin{array}{l}\text { Приволжский } \\
\text { федеральный округ }\end{array}$ & 1205 & 23,6 & 1194 & 23,4 & 1192 & 22,3 & -13 & $-1,3$ \\
\hline $\begin{array}{l}\text { Северо-Западный } \\
\text { федеральный округ }\end{array}$ & 226 & 4,4 & 224 & 4,4 & 246 & 4,6 & 20 & 0,2 \\
\hline $\begin{array}{l}\text { Северо-Кавказский } \\
\text { федеральный округ }\end{array}$ & 428 & 8,4 & 437 & 8,5 & 461 & 8,6 & 33 & 0,3 \\
\hline $\begin{array}{l}\text { Сибирский федеральный } \\
\text { округ }\end{array}$ & 555 & 10,9 & 540 & 10,6 & 557 & 10,4 & 2 & $-0,4$ \\
\hline $\begin{array}{l}\text { Уральский федеральный } \\
\text { округ }\end{array}$ & 305 & 6,0 & 320 & 6,3 & 322 & 6,0 & 17 & 0,1 \\
\hline $\begin{array}{l}\text { Центральный } \\
\text { федеральный округ }\end{array}$ & 1307 & 25,6 & 1303 & 25,5 & 1468 & 27,4 & 161 & 1,9 \\
\hline $\begin{array}{l}\text { Южный федеральный } \\
\text { округ }\end{array}$ & 899 & 17,6 & 892 & 17,5 & 904 & 16,9 & 5 & $-0,7$ \\
\hline $\begin{array}{l}\text { Российская Федерация } \\
\text { в целом: }\end{array}$ & 5112 & 100,0 & 5109 & 100,0 & 5349 & 100 & 236 & 0,0 \\
\hline
\end{tabular}

Таблица 2. Производство промышленной продукции в РФ за период 2014-2018 гг.

\begin{tabular}{|c|c|c|c|c|c|c|c|c|}
\hline \multirow{3}{*}{$\begin{array}{l}\text { Наименование феде- } \\
\text { рального округа }\end{array}$} & \multicolumn{6}{|l|}{ Годы } & \multirow{2}{*}{\multicolumn{2}{|c|}{ Динамика }} \\
\hline & \multicolumn{2}{|l|}{2016} & \multicolumn{2}{|l|}{2017} & \multicolumn{2}{|l|}{2018} & & \\
\hline & млн. руб. & $\%$ & млн. руб. & $\%$ & млн. руб. & $\%$ & млн. руб. & $\%$ \\
\hline $\begin{array}{l}\text { Дальневосточный } \\
\text { федеральный округ }\end{array}$ & 692 & 2,0 & 788 & 2,0 & 874 & 2,0 & 182 & 0,0 \\
\hline $\begin{array}{l}\text { Приволжский } \\
\text { федеральный округ }\end{array}$ & 7305 & 20,9 & 7942 & 20,5 & 9155 & 20,5 & 1850 & $-0,4$ \\
\hline $\begin{array}{l}\text { Северо-Западный } \\
\text { федеральный округ }\end{array}$ & 4696 & 13,4 & 5178 & 13,4 & 6035 & 13,5 & 1339 & 0,1 \\
\hline $\begin{array}{l}\text { Северо-Кавказский } \\
\text { федеральный округ }\end{array}$ & 397 & 1,1 & 405 & 1,0 & 438 & 1,0 & 41 & 0,0 \\
\hline $\begin{array}{l}\text { Сибирский федеральный } \\
\text { округ }\end{array}$ & 3488 & 10,0 & 3826 & 9,9 & 4473 & 10,0 & 985 & 0,1 \\
\hline $\begin{array}{l}\text { Уральский федеральный } \\
\text { округ }\end{array}$ & 4325 & 12,4 & 4760 & 12,3 & 5486 & 12,3 & 1161 & $-0,1$ \\
\hline $\begin{array}{l}\text { Центральный } \\
\text { федеральный округ }\end{array}$ & 11707 & 33,5 & 13197 & 34,1 & 15104 & 33,9 & 3397 & 0,4 \\
\hline $\begin{array}{l}\text { Южный федеральный } \\
\text { округ }\end{array}$ & 2358 & 6,7 & 2616 & 6,8 & 3035 & 6,8 & 676 & 0,1 \\
\hline $\begin{array}{l}\text { Российская Федерация } \\
\text { в целом: }\end{array}$ & 34967 & 100,0 & 38712 & 100,0 & 44600 & 100 & 9632 & 0,0 \\
\hline
\end{tabular}


Таблица 3. Валовой региональный продукт на душу населения за период 2014-2018 гг.

\begin{tabular}{|c|c|c|c|c|c|c|c|c|}
\hline \multirow{3}{*}{$\begin{array}{l}\text { Наименование феде- } \\
\text { рального округа }\end{array}$} & \multicolumn{6}{|l|}{ Годы } & \multirow{2}{*}{\multicolumn{2}{|c|}{ Динамика }} \\
\hline & \multicolumn{2}{|l|}{2016} & \multicolumn{2}{|l|}{2017} & \multicolumn{2}{|l|}{2018} & & \\
\hline & Тыс. руб. & $\%$ & Тыс. руб. & $\%$ & Тыс. ру6. & $\%$ & Тыс. руб. & $\%$ \\
\hline $\begin{array}{l}\text { Дальневосточный } \\
\text { федеральный округ }\end{array}$ & 577,7 & 16,2 & 599,2 & 16,0 & 628,2 & 15,6 & 50,5 & $-0,6$ \\
\hline $\begin{array}{l}\text { Приволжский } \\
\text { федеральный округ }\end{array}$ & 339,1 & 9,5 & 348,2 & 9,3 & 372,7 & 9,2 & 33,6 & $-0,3$ \\
\hline $\begin{array}{l}\text { Северо-Западный } \\
\text { федеральный округ }\end{array}$ & 520,2 & 14,6 & 556,8 & 14,9 & 588,5 & 14,6 & 68,3 & 0,0 \\
\hline 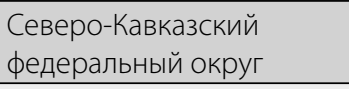 & 176,4 & 4,9 & 182,6 & 4,9 & 190,3 & 4,7 & 13,9 & $-0,2$ \\
\hline $\begin{array}{l}\text { Сибирский федеральный } \\
\text { округ }\end{array}$ & 353,1 & 9,9 & 367,2 & 9,8 & 401,8 & 9,9 & 48,7 & 0,1 \\
\hline $\begin{array}{l}\text { Уральский федеральный } \\
\text { округ }\end{array}$ & 737,3 & 20,7 & 767,5 & 20,5 & 864,5 & 21,4 & 127,2 & 0,7 \\
\hline $\begin{array}{l}\text { Центральный } \\
\text { федеральный округ }\end{array}$ & 580,7 & 16,3 & 616,5 & 16,5 & 666,4 & 16,5 & 85,7 & 0,2 \\
\hline $\begin{array}{l}\text { Южный федеральный } \\
\text { округ }\end{array}$ & 283,9 & 8,0 & 304,9 & 8,1 & 326,2 & 8,1 & 42,4 & 0,1 \\
\hline $\begin{array}{l}\text { Российская Федерация } \\
\text { в целом: }\end{array}$ & 3568,4 & 100,0 & 3742,9 & 100,0 & 4038,7 & 100 & 470,3 & 0,0 \\
\hline
\end{tabular}

на 0,3\%, а в Южном федеральном округе (ЮФО) - снижается на 0,7\% за период наблюдения. Суммарный объём производства сельскохозяйственной продукции на Юге России в 2018 году составил 1365 млн. рублей.

Доля Юга России в промышленном производстве за период 2016-2018 гг. оставалась неизменной и составила 7,8\%. Совокупный объём промпроизводства по итогам 2018 года составил 3473 млн. рублей.

Таким образом, мы можем характеризовать Юг России как индустриально-аграрный регион, промышленный комплекс которого является доминирующим в структуре формируемой добавленной стоимости. Вместе с тем, для субъектов Российской Федерации, входящих в состав Южно-Российского макрорегиона, характерна значительная социально-экономическая дифференциация, выражающаяся в различных факторах, в том числе - разнообразии форм экономической активности, детерминирующей различную структуру региональной экономики. В частности, в экономике Ростовской области важное место занимает энергетический комплекс, что обусловливается наличием на территории региона единственной на Юге России атомной электростанции, а также крупнейшей тепловой электростанции. В тоже время, в Краснодарском крае особую роль в структуре формирования валового регионального продукта играет туристско-рекреационный комплекс. В Республике Дагестан заметное место занимает производство сельскохозяйственной продукции. Принимая во внимание сказанное, не вызывает сомнений необходимость учёта факторов, определяющих региональную социально-экономическую специфику при разработке документов стратегического планирования на мезо- и макроэкономическом уровнях.

Как следует из информации, представленной в таблице 3, регионы Северо-Кавказского и Южного федеральных округов уступают другим субъектам Российской Федерации по такому показателю, как величина валового регионального продукта на душу населения. В частности, по итогам 2018 г. доля СКФО составила 4,7\%, доля ЮФО - 8,1\%, что в абсолютных значениях составляет 190,3 тыс. руб. и 326,2 тыс. руб. соответственно. Обозначенные значения существенно ниже общероссийского, составляющего 4038,7 тыс. руб.

Приведённое сравнение, на наш взгляд, подтверждает тот факт, что в настоящее время социально-экономический потенциал Юга России используется не в полной мере. Возникает необходимость снятия ограничений, затрудняющих поступательное развитие. Речь идёт о формировании благоприятной институционально-административной среды, стимулирующей реализацию инвестиционных проектов в субъектах Южно-Российского макрорегиона.

Одним из наиболее перспективных направлений инвестиционной активности является туристско-рекреационный комплекс. По мнению некоторых исследователей $[2,4,5]$, наибольший интерес для капиталовложений на современном этапе представляют такие сегменты 
туристско-рекреационной отрасли, как бальнеологический, гастрономический, этнографический, экологический, сельский туризм. В таких регионах Юга России, как Республика Крым, Республика Дагестан, Кабардино-Балкарская Республика и др. имеются все необходимые предпосылки для формирования качественных предложений для потребителей туристско-рекреационных услуг как в Российской Федерации, так и за её пределами.

В завершение необходимо сформулировать основные выводы:

1. Анализ структуры производства Южно-Российского макрорегиона показывает его преимущественно индустриально-аграрную ориентацию. При этом, в макрорегионе, в силу естественных природно-климатических факторов, имеются предпосылки для формирования высокопродуктивного агропромышленного комплекса, обеспечивающего продукцией сельскохозяйственного производства и переработки собственное потребление, а также спрос на мировом рынке. Дополнительным конкурентным преимуществом сельскохозяйственных товаропроизводителей Юга России является наличие прямого выхода к трём морям, что позволяет обеспечить поставку грузов заказчикам с минимальными издержками.

2. Имеющийся у регионов Юга России природный, культурный потенциал используется в настоящее время недостаточно эффективно. В частности, та- кая отрасль экономики, как туристско-рекреационная, не получила пока необходимого развития. Имеющиеся ограничительные факторы сдерживают приток инвестиций в макрорегион, что негативно отражается на уровне доходов граждан и качестве жизни. По показателю доли валового внутреннего продукта на душу населения, регионы Юга России отстают от других частей РФ.

3. Стимулировать социально экономическое развитие Южно-Российского макрорегиона возможно, реализовав ряд организационно-экономических и административно-правовых мероприятий, учитывающих факторы, определяющие региональную специфику субъектов РФ Южного и Северо-Кавказского федеральных округов. В частности, реализация налоговых преференций, ориентированных на хозяйствующие субъекты агропромышленного комплекса (налоговые каникулы, упрощение порядка формирования отчётности, дифференциация налоговых ставок и т.п.), позволит создать благоприятные условия для реализации инвестиционных проектов, сократить период их окупаемости [3]. Аналогичные меры стимулирования необходимо предпринять в отношении туристско-рекреационной отрасли. Реализация предлагаемых мероприятий позволит создать новые рабочие места, увеличить поступления налогов в бюджетную систему РФ, а также доходы граждан.

\section{ЛИТЕРАТУРА}

1. Абалкин Л. Экономическая безопасность России: угрозы и их отражение // Вопросы экономики. — 2011. — Т. 12.

2. Анопченко Т. Ю. Механизм развития туристско-рекреационного потенциала на мезоэкономическом уровне (на примере Республики Крым) / Анопченко Т. Ю., Мурзин А. Д., Ревунов Р. В. // Вестник Института дружбы народов Кавказа Теория экономики и управления народным х0зяйством. 2019. № 3 (51). C. 21.

3. Москаленко А.П. Инвестиционное проектирование: основы теории и практики Москаленко А. П., Москаленко С. А., Ревунов Р. В., Вильдяева Н.И. / Санкт-Петербург, 2018. (1-е, Новое)

4. Малинин А.М. Развитие сельского туризма в регионах России как форма повышения уровня социально-экономического развития региона / Малинин А. М., Андреева Д. А. // Известия Санкт-Петербургского государственного аграрного университета. 2016. № 44. С. $204-209$.

5. Менщикова В.И. Факторы устойчивого развития регионов России (книга 10) / Под. общ. ред. С. С. Чернова. — Новосибирск. - 2011.

6. Официальный сайт Росстата https://www.gks.ru

7. Регионы России. Социально-экономические показатели. 2019: Стат. сб. / Росстат. М., 2019. 1204 с.

8. Шевлоков В. Концепция устойчивого регионального развития и прогнозная модель социально-экономического развития аграрно-промышленного региона / Шевлоков В., Казанчева Х. // Международный сельскохозяйственный журнал. 2008. № 6. С. 31-34.

9. Pryadko I. A. Promotion of educational services in social networks / Pryadko I. A., Paytaeva K. T., Revunov R. V., Zelenova G. V., Evetskaya S. V. // Advances in Intelligent Systems and Computing. 2019. T. 726. C. 931-942.

(c) Рамазанова Марина Юсуфовна (Eminowa.marina@yandex.ru). Журнал «Современная наука: актуальные проблемы теории и практики» 